\title{
Preservação do Deutschtum nas escolas da imigração alemã no período da Campanha de Nacionalização
}

\author{
Preservation of Deutschtum in German immigration schools during the period of the Nationalization Campaign \\ Preservación del Deutschtum en las escuelas de inmigración alemana en el período de la Campaña de \\ Nacionalización
}

Débora de Lima Velho Junges - Instituto Federal Catarinense | Técnica em Assuntos Educacionais | Fraiburgo | SC | Brasil. E-mail: deborajunges@gmail.com

Resumo: Este artigo tem como objetivo analisar como o Deutschtum se fazia presente nas vivências dos descendentes de imigrantes alemães enquanto estudantes nas escolas da imigração alemã durante o período da Campanha de Nacionalização. As ferramentas teóricas do estudo estão vinculadas aos estudos e pesquisas relacionadas à imigração alemã e às teorizações foucaultianas. O material de pesquisa consiste em narrativas de sete pessoas que estudaram em escolas da imigração alemã no Rio Grande do Sul, no período citado. Os principais resultados da investigação apontam que os princípios norteadores do Deutschtum foram, em alguns casos, preservados e, até mesmo, reforçados no período da Campanha de Nacionalização em forma de rituais escolares "adaptados" às condições impostas pelas medidas de Estado.

Palavras-chave: Campanha de Nacionalização. Deutschtum. Subjetivação.

Abstract: This article aims to analyze how the Deutschtum was present in the experiences of the descendants of German immigrants as students in German immigration schools during the period of the Nationalization Campaign. The theoretical tools of the study are linked to studies and research related to German immigration and Foucaultian theorizations. The research material consists of narratives of seven people who studied in schools of German immigration in the Rio Grande do Sul, during the mentioned period. The main research results indicate that the guiding principles of Deutschtum were in some cases preserved and even reinforced during the period of the Nationalization Campaign in the form of school rituals "adapted" to the conditions imposed by State measures.

Keywords: Nationalization Campaign. Deutschtum. Subjectivation.

Resumen: Este artículo tiene como objetivo analizar cómo el Deutschtum se hacía presente en las vivencias de los descendientes de inmigrantes alemanes como estudiantes en las escuelas de la inmigración alemana durante el período de la Campaña de Nacionalización. Las herramientas teóricas del estudio están vinculadas a los estudios e investigaciones relacionadas con la inmigración alemana y las teorizaciones foucaultianas. El material de investigación consiste en narrativas de siete personas que estudiaron en escuelas de la inmigración alemana en Rio Grande do Sul, en el período citado. Los principales resultados de la investigación apuntan que los principios orientadores del Deutschtum, en algunos casos, se preservaron y se reforzaron en el período de la Campaña de Nacionalización en forma de rituales escolares "adaptados" a las condiciones impuestas por las medidas de Estado.

Palabras clave: Campaña de Nacionalización. Deutschtum. Subjetividad.

- Recebido em 30 de novembro de 2018 • Aprovado em 02 de setembro de 2019 • e-ISSN: 2177-5796

DOI: http://dx.doi.org/10.22483/2177-5796.2019v21n3p725-744

Copyright @ 2019. Conteúdo de acesso aberto, distribuído sob os termos da Licença Internaonal da CreativeCommons - CC BY-NC-SA Atribuição Não Comercial (https://br.creativecommons.org/licencas/) - Permite distribuição e reprodução, desde que atribuam os devido créditos à publicação, ao autor(es) e que licenciem as novas criações sob termos idênticos. 


\section{Introdução}

A Campanha de Nacionalização, que iniciou com os decretos de 1938 relacionados à restrição do uso do português como língua única do país e culminou em 1945, é considerada por estudiosos e pesquisadores da imigração alemã no Brasil como um dos elementos que intervieram no declínio das escolas da imigração alemã no território nacional e consequente fechamento destas em colônias alemãs (KREUTZ, 1994; RAMBO, 1994). No estado do Rio Grande do Sul, pela imposição das medidas que buscavam a nacionalização do ensino, "criou-se um clima de tensão e medo na região colonial dos imigrantes" (KREUTZ, 2010, p. 81-82).

Nesse cenário, os imigrantes alemães e seus descendentes passaram a vivenciar um dilema, pois, enquanto cidadãos brasileiros, estes deviam acatar as legislações vigentes. Todavia, o sentimento de pertencimento à nação alemã, perpetuado pela conservação e pela prática do Deutschtum, operava em suas vidas, subjetivando-os de modo a se perceberem como colonos, no qual a descendência alemã era priorizada. Vale ressaltar que, na tradição alemã do século XIX, a noção de Deutschtum (germanismo) introduz "a ideia de que a nacionalidade é herdada, produto de um desenvolvimento físico, espiritual e moral: um alemão é sempre alemão, ainda que tenha nascido em outro país” (SEYFERTH, 1982, p. 46).

Quanto às formas de vida escolar, antes das medidas impostas pelo Estado, os princípios norteadores do germanismo “eram transmitidos na escola, através do currículo, do conteúdo programático, dos livros didáticos, através da língua alemã e da ação dos professores" (FONSECA, 2007, p. 105). Como procuraremos discutir, tais princípios norteadores do germanismo foram, em alguns casos, preservados e, até mesmo, reforçados no período da Campanha de Nacionalização em forma de rituais adaptados às novas condições.

Tal como em Foucault (2011), compreendemos os rituais como procedimentos que legitimam a manifestação da verdade, sejam eles na ordem do dito, do enunciado ou do que foi expresso, como também de outros procedimentos postos em ação na prática social. No contexto deste estudo, os rituais são aqueles que se relacionam às especificidades subjetivas e objetivas que eram praticadas nas escolas da imigração alemã.

De modo mais específico, este artigo tem como objetivo analisar como o Deutschtum, o sentimento de pertencimento e a atitude de respeito à cultura alemã se fazia presente nas vivências dos descendentes de imigrantes alemães enquanto estudantes nas escolas da imigração 
alemã durante o período da Campanha de Nacionalização. Para isso, foram produzidas narrativas com sete pessoas que estudaram em escolas da imigração alemã no período compreendido entre 1938 a 1945.

\section{O Deutschtum e o período da Campanha de Nacionalização}

Antes de mais nada, é relevante, para as discussões que serão tratadas neste artigo, considerar a atmosfera que compunha o cenário no qual as escolas da imigração estavam inseridas e apresentar quais aspectos circundavam as relações estabelecidas entre Brasil e Alemanha nesse período. Isto porque o enunciado de uma possível ameaça à constituição de uma nacionalidade brasileira pela preservação e prática do Deutschtum em território nacional circulava no Estado, na sociedade brasileira e entre os imigrantes alemães e seus descendentes, e encontrou terreno fértil com a ascensão do nazismo em 1933 até o final da Segunda Guerra Mundial (SEYFERTH, 2002; WEBER, 2012).

Em sua tese, Rahmeier (2009) estudou as relações diplomáticas, políticas e militares estabelecidas entre Alemanha e Brasil da metade da década de 1930 até a declaração brasileira de guerra à Alemanha, em 1942. A autora observa que antes de 1937 "as relações diplomáticas da Alemanha com o Brasil eram guiadas pelas necessidades comerciais de ambos os países" (RAHMEIER, 2009, p. 81) e, também, por razões políticas. Havia uma forte tendência de crescimento e estreitamento entre as relações comerciais e políticas dos dois países, posto que, do lado alemão, se fazia necessário um grande volume de matérias-primas diversificadas e de produtos agrícolas que eram encontrados no Brasil.

Além disso, a Alemanha "também necessitava de um mercado consumidor para seus inúmeros produtos industrializados" (RAHMEIER, 2009, p. 89) e encontrou no Brasil a abertura necessária para exportação dos produtos manufaturados. Outro fator que intensificou as relações comerciais "foi a possibilidade do comércio de compensação entre Brasil e Alemanha atender às intenções das forças armadas do Brasil, pois permitia a compra de material bélico das empresas alemães" (RAHMEIER, 2009, p. 89).

Até 1937, as divergências na concepção de nacionalismo entre os dois países pouco afetaram a relação diplomática estabelecida e os apoios comerciais e políticos entre ambos. Contudo, a partir da implementação do Estado Novo, as relações entre Brasil e Estados Unidos se 
intensificaram e se tornaram cada vez mais consistentes. Nesse período, ocorreu o "fechamento dos acordos comercias, de criação da siderurgia e de compra de armamentos do Brasil dos Estados Unidos” (RAHMEIER, 2009, p. 248), o que repercutiu de maneira negativa nos apoios comerciais, políticos e bélicos constituídos até então entre Brasil e Alemanha.

Das mudanças que se seguiram no governo de Getúlio Vargas com a criação e a imposição do Estado Novo e a outorga de uma nova Constituição em 1937, algumas afetaram direta ou indiretamente a relação diplomática entre Brasil e Alemanha, assim como repercutiram na vida dos imigrantes alemães e seus descendentes (RAHMEIER, 2009). Entre elas, se destacam a Campanha de Nacionalização (ao impor ações direcionadas às comunidades de imigrantes e seus descendentes e também ações contra cidadãos alemães que por ventura estivessem em território brasileiro), a proibição dos partidos estrangeiros (incluindo o Partido Nazista no Brasil) e a vinculação na mídia nacional de reportagens negativas sobre a Alemanha.

A partir dessas mudanças na política interna do Brasil, "a diplomacia germânica começou a intervir oficialmente junto ao governo brasileiro, em defesa de seus compatriotas, que se viam perseguidos, sendo que os dois governos estavam defendendo sua concepção de nacionalismo" (RAHMEIER, 2009, p. 31). Uma das principais diferenças que distinguem a concepção de nacionalismo entre Alemanha e Brasil se dá em um marco temporal. Ao passo que o Brasil de Getúlio Vargas procurava construir sua nacionalidade se voltando para o futuro, na Alemanha (assim como ocorria na maioria dos países europeus) a noção de Nação estava consolidada e havia um imperativo pela preservação do Deutschtum (germanidade).

Outro ponto que distinguia a concepção de nacionalismo nos dois países era a compreensão jurídica de cidadania. No Brasil, era empregado "o princípio do jus soli, onde cidadania e nacionalidade são coisas indistintas e definidas pelo solo de nascimento, ou seja, quem nasce em solo brasileiro é brasileiro" (NEUMANN, 2009, p. 135). Assim, para o Estado Novo, os imigrantes e descendentes que não haviam nascido no território brasileiro permaneciam na condição de estrangeiros e eram considerados uma ameaça para a unidade nacional (SEYFERTH, 2008).

No caso alemão, nacionalidade e cidadania eram termos distintos conforme o princípio que operava do jus sanguinis. Segundo este princípio "a nacionalidade é transmitida pelo sangue, assim, em qualquer lugar, um alemão sempre permanece como tal; já a cidadania é dada pelo local de nascimento" (NEUMANN, 2009, p. 135). Ou seja, mesmo que o descendente de um 
imigrante alemão nascesse no Brasil, sua nacionalidade era considerada alemã pelo entendimento jurídico desse país. Além disso, essa compreensão pressupõe que a nacionalidade alemã, ou o Deutschtum, é “perpetuada, mesmo longe da pátria de origem, através da cultura, do idioma e dos demais costumes alemães" (DIAS, 2006, p. 23).

Enquanto na Alemanha se lutava pela manutenção da continuidade do Deutschtum, mesmo em território não-alemão, o Estado Novo passou a repudiar manifestações culturais e étnicas que em seu entendimento poderiam interferir negativamente na construção do ideal de um nacionalismo brasileiro. Assim, a preservação e as formas de manifestação do Deutschtum pelos imigrantes e seus descendentes que até 1937 era, de certa forma, aceita pelo governo brasileiro, passou a ser um problema a ser combatido em nível nacional (DIAS, 2006).

Vale ressaltar que o Deutschtum "é umas das categorias centrais do germanismo, corrente de pensamento que se difundiu no Rio Grande do Sul a partir do final do século XIX e durante as primeiras quatro décadas do século XX” (ARENDT, 2005, p. 95). Referente à nacionalidade alemã, esse termo, que se originou do pensamento romântico-nacionalista e sofreu influência das teorias raciais (GRÜTZMANN, 2008), é concebido por diferentes vertentes da bibliografia alemã como "os traços culturais particulares desse grupo - língua, religião, sistema de parentesco etc. que são capazes de oferecer crenças, regras de conduta e valores morais” (DIAS, 2006, p. 22).

A constituição da subjetivação "precisa se desenvolver em termos da relação entre as tecnologias para o governo da conduta e as técnicas intelectuais, corporais e éticas que estruturam a relação do ser consigo mesmo em diferentes momentos e locais” (ROSE, 2001, p. 45). Nesse sentido, compreende-se que o Deutschtum operava como uma tecnologia na produção de uma subjetividade específica na forma de vida alemã (sendo esses sujeitos residentes ou não da Alemanha, considerando o princípio jurídico do jus sanguinis), ao estabelecer um conjunto de princípios e regras que atuava na relação do ser consigo e com os outros.

As práticas de subjetivação, atreladas ao ideal de manutenção do Deutschtum, operavam na produção e transformação das experiências dos alemães, tanto no campo individual (da constituição e transformação de si mesmo), quanto coletivo (na condução e na relação com o outro). Uma vez que as tecnologias, "são vivenciadas/aplicadas/constituídas na experiência social dos sujeitos" (BUJES, 2002, p. 6), o germanismo se inseria como uma tecnologia que constituiu um modo de ser que possuía particularidades relacionadas aos valores, mitos e tradições de uma nacionalidade alemã. 
No contexto no Rio Grande do Sul, a luta pela manutenção e preservação do Deutschtum é praticamente unanimidade entre os historiadores da imigração alemã. Kreutz (2007, 2010), Seyferth (1997, 2008), Arendt (2005), Dias (2006) e Grützmann (2008) são alguns que evidenciam que entre os imigrantes alemães e seus descendentes se procurou conservar e, até mesmo, reproduzir o que consideravam representar o "bem cultural germânico", vinculado a um sentimento de pertencimento étnico e cultural. Entretanto, é importante ressaltar que, mesmo buscando a continuidade do Deutschtum, os imigrantes alemães e seus descendentes procuraram se integrar a sociedade e adquirir a cidadania brasileira (WITT, 2008), ou seja, eles não se mantiveram as margens do restante da sociedade.

A partir da segunda metade do século XIX, principalmente pela imprensa em alemão, se difundiu com intensidade "a ideia de que os imigrantes alemães e seus descendentes deveriam conservar a sua identidade, denominada de germanidade (Deutschtum) e, assim, manter os laços étnico-culturais com a Alemanha" (GRÜTZMANN, 2008, p. 1). Essa ideia se vinculou a três diferentes vertentes no Rio Grande do Sul que, apesar de serem representadas por diferentes líderes, tinham em comum a luta pela defesa da germanidade. As vertentes eram: de pastores luteranos (líderes das comunidades evangélicas luteranas), de padres jesuítas (que lideravam a população católica de ascendência alemã) e dos Brummer (que não estavam vinculados a uma religião específica) (ARENDT, 2005).

Se por um lado os imigrantes alemães e seus descendentes foram subjetivados pelo discurso do germanismo, a partir da década de 1930, eles passaram a serem pressionados pelos governos federais e estaduais que pretendiam "a nacionalização do elemento estrangeiro e a supressão de qualquer grupo etnicamente homogêneo, defendendo a 'mistura de raças' para a formação do povo brasileiro" (ARENDT, 2005, p. 107).

No contexto da Campanha de Nacionalização, os imigrantes alemães e seus descendentes passaram a vivenciar um dilema, pois, enquanto cidadãos brasileiros, estes deviam acatar as legislações vigentes, que nesse caso suprimiam as manifestações culturais e étnicas consideradas pelo Estado desvinculadas com a sua concepção de nacionalismo. Todavia, o sentimento de pertencimento à nação alemã gerava certos conflitos entre os imigrantes alemães e seus descendentes e os representantes da lei (RAHMEIER, 2009).

"Mesmo que Getúlio Vargas, pelas suas ações, concordasse e adotasse alguns métodos considerados nazistas, não admitia aos estrangeiros interferirem ou incentivarem a preservação de 
uma cultura não brasileira" (RAHMEIER, 2009, p. 101). Tais atos repercutiram negativamente nas relações entre o governo brasileiro, o Estado alemão e o Partido Nazista. Entretanto, ao contrário do que apontam autores da historiografia tradicional da imigração alemã, Rahmeier (2009), ao analisar a documentação militar e diplomática existente no Arquivo Nacional Alemão, observou que a Campanha de Nacionalização não foi a maior motivadora da crise diplomática entre Alemanha e Brasil após 1938.

A Campanha de Nacionalização provocou descontentamentos, mas a diplomacia alemã compreendia que não poderia intervir na nova legislação brasileira. Nesse caso, as ações diplomáticas expressas pelos documentos oficiais dão conta dos interesses dos cidadãos alemães em termos de prisões e da preocupação com a escolarização em língua portuguesa.

"Percebe-se que o cerne da questão era o choque entre as ideias de nacionalismo" (RAHMEIER, 2009, p. 359). A discordância se dava na questão da preservação e prática do Deutschtum em território brasileiro em oposição da política nacionalista do governo de Vargas, que desejava criar uma nação brasileira na qual todos que residiam no Brasil deveriam ter uma cultura comum. Na narrativa dos participantes desta pesquisa, são notórias a manutenção e a importância da germanidade em suas histórias de vida, juntamente com a questão de como se viam como cidadãos brasileiros.

\section{Procedimentos teórico-metodológicos}

Conforme abordado, a Campanha de Nacionalização teve grandes implicações para as comunidades de imigração alemã, em especial, produzindo tensionamentos em escolas situadas neste contexto. Tal período temporal se constitui como relevante na trajetória da escolarização da imigração alemã. Por essa razão foi definido como sujeitos dessa pesquisa um grupo de pessoas que frequentaram escolas da imigração alemã no período da Campanha de Nacionalização, entre 1938 e 1945.

O grupo de sete $^{1}$ participantes foi entrevistado durante o ano de 2013 , sendo que estes tinham idades que variavam de 78 a 85 anos. O grupo era dividido em quatro mulheres e três homens que residiam em Parobé e Taquara no momento das entrevistas, municípios do Rio Grande do Sul.

\footnotetext{
${ }^{1}$ Para manter o anonimato dos participantes da pesquisa, eles foram identificados pelos seguintes nomes: Helga, Rose, José, Breno, Veni, Renata e Germano. 
JUNGES, Débora de Lima Velho. Preservação do Deutschtum nas escolas da imigração alemã no período da Campanha de Nacionalização.

Para a escolha dos participantes do estudo, inicialmente foram contatados os administradores de dois asilos dos municípios de Taquara e Parobé. Foram eles que, após terem sido informados dos objetivos da pesquisa, fizeram a seleção dos residentes, segundo o critério: haver frequentado alguma escola da imigração alemã, da região, no período da Campanha de Nacionalização.

Com cada um dos participantes foi realizada mais de uma entrevista individual, de modo a produzir narrativas, em conformidade com as formulações da metodologia de Storytelling (JØRGENSEN; BOJE, 2010). Isso implicou em não conduzir a fala dos entrevistados de modo a conformá-la como texto linearizado (com um começo, meio e fim).

Na perspectiva da Storytelling, aquele que fala passa a ter a liberdade de contar a sua história do modo que lhe for conveniente, sem que haja a delimitação do que falar e como organizar sua fala. Na produção das narrativas, procuramos nos afastar da realização de entrevistas estruturadas que enfocassem, unicamente, o objetivo da pesquisa, já que essa modalidade de entrevista pode induzir a um viés menos subjetivo (JØRGENSEN; NUNEZ, 2010).

Por se constituir como uma prática discursiva, a narrativa e, consequentemente, a perspectiva metodológica de Storytelling, também está imbricada em relações de poder (JØRGENSEN; NUNEZ, 2010) que penetram "muito profundamente, muito sutilmente em toda a trama da sociedade" (FOUCAULT, 2002, p. 71). Assim, a narração, como uma prática discursiva, também se submete aos procedimentos organizacionais, seletivos e restritivos de proferimento das palavras (FOUCAULT, 1998). Em suma, a narrativa é compreendida em termos da relação do narrador consigo mesmo e com os outros, operando em determinados tempos e espaços (JØRGENSEN; NUNEZ, 2010).

Tendo como orientadores os preceitos da metodologia de Storytelling, as entrevistas (gravadas e posteriormente transcritas) foram concedidas nas dependências dos dois asilos da região, onde residiam os participantes ${ }^{2}$. Tais entrevistas foram longas, com duração média de duas horas cada. Em vários momentos, eles recordaram vivências ocorridas em períodos

\footnotetext{
${ }^{2}$ Cabe, aqui, também ressaltar que todos os participantes assinaram o Termo de Consentimento Livre e Esclarecido, após serem informados sobre os objetivos da pesquisa, de acordo às normas de ética nas pesquisas em Ciências Humanas e Sociais. Além disso, o Projeto de Pesquisa tramitou pelo Comitê de Ética em Pesquisa da Universidade à qual o estudo esteve vinculado e foi aprovado, por estar adequado ética e metodologicamente, conforme os preceitos da Resolução 466/12 do Conselho Nacional de Saúde.
} 
JUNGES, Débora de Lima Velho. Preservação do Deutschtum nas escolas da imigração alemã no período da Campanha de Nacionalização.

anteriores e posteriores aos da Campanha de Nacionalização. Nessas ocasiões, procuramos ter o cuidado de não os interromper, uma vez que, às vezes, essas fugas acabavam introduzindo algo relacionado com o período em que frequentaram a escola da imigração alemã.

\section{O Deutschtum nas escolas da imigração alemã}

Diversas observações a respeito do "ser alemão" e do "ser brasileiro" podem ser realizadas a partir das narrativas produzidas pelos participantes desta pesquisa, uma delas é a de que os imigrantes alemães e seus descendentes procuravam manter e perpetuar as tradições, os costumes e os traços culturais e étnicos provenientes da Alemanha, mesmo se considerando como cidadãos brasileiros. Ou, dito de outra forma, o Deutschtum operava na vida dos imigrantes alemães e seus descendentes, subjetivando-os de tal modo que eles se percebiam como colonos de descendência alemã e cidadania brasileira.

Um dos elementos que corroboram com o argumento anterior está relacionado ao pertencimento a uma família de origem alemã. $\mathrm{Na}$ fala dos participantes, se pode perceber certo orgulho por serem filhos ou netos de imigrantes vindos da Alemanha e terem o "sobrenome alemão". Isto está presente nos seguintes fragmentos: “é que eu cresci aprendendo as tradições de família como era quando os meus pais moravam na Alemanha. Isso era motivo de orgulho pra mim. Saber as coisas de lá. Assim era como se eu também tivesse nascido como alemã e não como brasileira" (Rose); "eu tenho sim orgulho de ter sobrenome alemão. Minha família por parte de pai é de uma família tradicional. Então eu sempre procurei passar pros meus filhos o que eu aprendi em casa, na escola, em como ter orgulho de ser de família alemã (Breno); “eu sei que minha família toda tem sobrenome alemão, então um pouco de alemã eu também sou" (Helga).

As narrativas apresentadas evidenciam o sentimento de preservação às "tradições alemãs" e buscam pela perpetuação de uma determinada "cultura alemã" aos seus descendentes, a fim de que os mesmos pudessem manter viva a germanidade proveniente de suas famílias. Algo que os defensores do germanismo procuravam promover entre os imigrantes (GRÜTZMANN, 2008).

Em um dos momentos de sua narrativa, José afirmou que "mesmo que nascendo aqui no Brasil, eu aprendi a ser colono, a preservar os costumes que meus pais tinham quando moravam lá [na Alemanha]. Porque assim era o certo pra mim, entende?’. E, logo em seguida, 
JUNGES, Débora de Lima Velho. Preservação do Deutschtum nas escolas da imigração alemã no período da Campanha de Nacionalização.

acrescentou: "eu me sentia mais alemão que brasileiro, porque eu me criei com os costumes dos meus pais. E eu nunca perdi isso, de valorizar as tradições. Acho que é importante preservar as tradições, porque senão vai se esquecendo da onde a gente vem". A fala de preservação e valorização dos costumes originários da cultura alemã e transmitidos pelos pais de José o constituiu enquanto filho de imigrantes alemães e operou de tal maneira que o levou a se identificar mais com a nacionalidade alemã do que com a nacionalidade brasileira.

O mesmo é observado na narrativa de Rose ao demonstrar orgulho de ter aprendido as tradições da família de origem alemã: "é que eu cresci aprendendo as tradições de família como era quando os meus pais moravam na Alemanha. Isso era motivo de orgulho pra mim". Já Helga, ao se autodenominar como "alemoa", percebe que foram os enunciados presentes no meio em que vivia que a constituíram como tal, por serem tomados como verdadeiros para ela. No trecho, "quando eu falo de ser um pouco alemoa, eu quero dizer que algumas coisas que meus avós trouxeram de lá [da Alemanha] eu aprendi e continuei fazendo", essas "coisas" são a fala do alemão, as receitas de comidas tradicionais da Alemanha e as orações alemãs, todas relacionadas aos traços culturais que compunham a germanidade. "Saber as coisas de lá [da Alemanha] me fazia me sentir bem. Assim era como se eu também tivesse nascido como alemã e não como brasileira. Então eu aprendia tudo que podia, que nem fazer as comidas tradicionais que a minha mãe me ensinava a fazer e eu ajudava ela na cozinha. Ou, também, saber os hinos da igreja em alemão, que eu rezava todas as noites" (Rose).

Breno também considerou os costumes de sua família como uma tradição a ser perpetuada e que o impeliram a se ver por um tempo como "colono alemão": "o que eu quero dizer é que mesmo sendo brasileiro de nascimento, minha família é de origem alemã e eu aprendi a ser colono e os costumes com eles". Contudo, se percebe que esta visão de si como alemão sofreu alterações com o passar do tempo: "não é que eu era alemão, eu me sentia como se tivesse nascido lá [na Alemanha]. Mas a verdade é que eu sou um colono brasileiro, porque nasci aqui $n e$ ".

As práticas de subjetivação são transformadas e modificadas ao longo dos anos de acordo a episteme de cada época. Isso faz com que as práticas de poder que conformam os indivíduos também sofram alterações específicas considerando os diferentes espaços e tempos históricos (FOUCAULT, 2011). Nesse sentido, é possível analisar a mudança presente na enunciação de Breno em relação a si (primeiramente enquanto "colono alemão" e, posteriormente, se 
considerando como "colono brasileiro"), como inserida na trama das tecnologias que o objetivaram (na sua relação com o que lhe é externo) e o subjetivaram (na relação consigo mesmo), levando-o a estabelecer um significado diferente para a sua nacionalidade.

O uso da língua alemã está presente nos excertos das narrativas apresentadas como outro fator que estabelece uma ligação próxima entre eles e a nacionalidade alemã. Nesse período, o uso da língua alemã no Brasil era considerado por defensores do nacionalismo brasileiro e também pelo Estado como uma ameaça ao intento da formação e unificação de uma nação legitimamente brasileira, pois estabelecia uma ligação direta com o nacionalismo alemão (SEYFERTH,1997). Esse era um ponto de preocupação tão expressivo que uma das primeiras e considerada por estudiosos da imigração alemã como uma das principais medidas postas em ação durante a Campanha de Nacionalização, se deu justamente com a proibição do uso de línguas estrangeiras (KREUTZ, 2010; SEYFERTH, 1997).

A noção de nação é fundamentada em representações simbólicas que constituem uma identidade cultural específica (HALL, 2006). Uma dessas representações simbólicas é a generalização de "uma única língua vernacular como o meio dominante de comunicação em toda a nação" (HALL, 2006, p. 49). Ao usar o alemão como primeira língua para se comunicar no período em que estudaram nas escolas da imigração alemã, os participantes dessa pesquisa reforçam os sentimentos de identificação e, até mesmo, pertencimento à cultura germânica.

Vale ressaltar que na defesa do Deutschtum o uso da língua alemã é um dos elementos que caracteriza a nação alemã. "A ligação com a Alemanha, portanto, baseia-se na comunidade de sangue e língua, naturalizada através de um modo de vida alemão preservado nas colônias" (SEYFERTH, 1994, p. 6).

Outro ponto que merece destaque nas narrativas dos participantes da pesquisa é em relação ao uso constante da expressão "eu aprendi” ao se reportarem à forma de vida da imigração alemã e do ser/se sentir como alemão/colono. Os seguintes excertos apresentam esta relação entre aprender as tradições e os costumes da imigração alemã e a constituição dos entrevistados: "[...] eu aprendi a ser colono, a preservar os costumes" (José); "eu cresci aprendendo as tradições de família" (Rose); "minha família é de origem alemã e eu aprendi a ser colono e os costumes com eles" (Breno); "quando eu falo de ser um pouco alemoa, eu quero dizer que algumas coisas que meus avós trouxeram de lá [da Alemanha] eu aprendi e continuei fazendo" (Helga). 
$\mathrm{O}$ ato de aprender consiste em "um preceito de transformação que traça um caminho de exercício constante, no qual o indivíduo se produz como uma permanente individualização" (MARIN-DÍAZ, 2012, p. 123). Assim, aprender é uma ação contínua na qual o indivíduo age sobre si mesmo com o intuito de se modificar, de se transformar, de adquirir outras e novas habilidades e comportamentos. José, Rose, Breno e Helga, ao afirmarem que aprenderam com seus familiares modos de vida provenientes da imigração alemã, se mobilizaram e atuaram sobre si mesmos, na sua própria condução, de maneira que esses traços culturais germânicos lhes fossem significativos a ponto de se reconhecerem (até a realização das entrevistas ou durante um período de suas trajetórias de vida) como colonos/alemães.

\section{Rituais escolares que operavam a favor da manutenção do Deutschtum}

Vinculadas a um processo acionado pelo ideário germanista (Deutschtum) de manter o vínculo com a cultura alemã no Brasil pela conservação da língua materna, e como recurso para a diferenciação e identificação dos imigrantes e de seus descendentes, as aulas nas escolas da imigração alemã eram dadas, quase integralmente, em alemão até o início da Campanha de Nacionalização (ARENDT, 2005). Com os decretos efetivados pelo Estado Novo, estabeleceramse tecnologias de controle sobre a população que visavam não excluir os imigrantes alemães e seus descendentes, mas integrá-los, seguindo as intencionalidades do governo. Exemplos disso foram a obrigatoriedade do uso da língua portuguesa, a criação das Caravanas Nacionalistas - que procuravam disseminar o culto à pátria -, e a obrigatoriedade do ensino cívico, de Geografia e de História do Brasil (WANDERER, 2014).

Neste contexto, das enunciações dos entrevistados destacamos três rituais escolares que operaram em favor do discurso de manutenção do Deutschtum. O primeiro se relacionava ao ritual escolar de ensinar, aprender e entoar o hino da Alemanha e evidencia que esta prática fazia parte dos rituais escolares dessa forma de vida e que para os alunos dessas escolas entoar o hino era uma demonstração de orgulho e respeito por terem descendência alemã.

Os participantes da pesquisa relataram que havia sido na escola que aprenderam a cantar o hino da Alemanha e, além disso, entoar o hino se configurava como uma prática escolar recorrente na programação semanal. Conforme Germano, "lembro que de tudo o que aprendi do povo alemão, uma das primeiras coisas que aprendi foi o hino alemão", ele ainda observou que 
"quase sempre no início da aula a gente cantava, que era pra não esquecer das frases. Também se cantava quando tinha algum tipo de competição entre nós que estudava lá. Como jogos". Helga narrou: "foi na escola também que eu aprendi o hino alemão. A gente cantava ele uma vez por semana, antes da aula começar". E Veni comentou: "eu lembro que foi na escola que eu aprendi o hino da Alemanha e nunca mais esqueci”.

Entretanto, em tais espaços também era ensinado e cantado o hino nacional do Brasil, mesmo antes das leis que instituíram a obrigatoriedade do canto do hino com o hasteamento da bandeira nacional e de ensaiar os hinos pátrios (como os da Bandeira, da Independência e da República). Até mesmo alguns livros didáticos utilizados em escolas da imigração alemã continham as letras dos hinos oficiais brasileiros (DIAS, 2006). Porém essa prática ocorria de maneira diferente do que em relação ao canto do hino alemão.

Antes das medidas estabelecidas na Campanha de Nacionalização, cantar o hino brasileiro não era uma prática tão frequente quanto cantar o hino alemão: “mas antes a gente cantava sempre da Alemanha primeiro e, às vezes, do Brasil. Mas não era muito não" (Germano); "não é que a gente não sabia o hino do Brasil, mas o que era o mais cantado era o da Alemanha" (Veni).

Com as medidas nacionalistas que procuravam promover a unificação do Estado brasileiro, por meio da criação de uma identidade nacional, o canto do hino se constituiu como uma ferramenta de divulgação dos ideais de admiração e respeito à pátria (PAULA, 2006). No entanto, mesmo com a obrigatoriedade e a ampliação da frequência do canto do hino brasileiro como um ritual escolar, ela era realizada de maneira diferente pelos alunos. Se por um lado, o respeito e o posicionamento dos corpos dos estudantes era o mesmo do que quando eles entoavam o hino da Alemanha, o "entusiasmo" em fazê-lo era menor.

Segundo Germano "quando foi proibido da gente cantar o hino na escola, a gente já sabia o hino brasileiro, aí só cantávamos esse", mas “todos os meus colegas também queriam cantar o hino da Alemanha que era mais bonito, mais pomposo. Ai a gente não cantava o do Brasil com tanta empolgação, porque não se gostava tanto. Mas sempre foi com muito respeito". Além de relatar que o hino brasileiro não era executado com "tanta empolgação" quanto ocorria com o hino alemão, Germano ainda observou que a frequência em que se cantava o hino brasileiro também era menor do que quando se podia entoar o hino da Alemanha. 
JUNGES, Débora de Lima Velho. Preservação do Deutschtum nas escolas da imigração alemã no período da Campanha de Nacionalização.

A mesma diferença em relação à execução dos dois hinos é narrada por Veni. Antes da Campanha de Nacionalização ela relatou que "na escola eu cantava com mais vontade o hino alemão do que o do Brasil, que a gente cantava pouco até. Só mais quanto tinha as atividades da pátria, das comemorações que tinha na escola". Com a proibição da língua alemã, "ficou só o do Brasil, mas não era a mesma coisa. Ninguém cantava com tanto entusiasmo sabe, era diferente. Mas a gente aprendeu todos os hinos, o hino do Brasil, da Bandeira, da Proclamação, Independência. Tudo bem certinho".

Diante de tais narrativas, é possível afirmar que entoar os hinos nacionais brasileiro e alemão se constituía como um ritual escolar nas escolas da imigração alemã, mas existiam diferenças na execução dos mesmos. Enquanto podiam cantar o hino da Alemanha, os alunos de tais escolas o faziam com mais frequência e entusiasmo. No entanto, ao ser proibida sua execução, o hino do Brasil passou a ser entoado como uma obrigação em momentos direcionados a demonstração de patriotismo e com menos entusiasmo.

O segundo ritual escolar analisado foi o uso da língua alemã na forma de vida escolar. Das vivências narradas pelos participantes dessa pesquisa, foi observada a ocorrência de uma manutenção do uso da língua alemã no espaço escolar em situações específicas, as quais requeriam dos indivíduos envolvidos certo cuidado para que não fossem ouvidos. Nesse sentido, os alunos e, até mesmo, alguns professores, em um movimento de contraconduta (VEIGANETO; LOPES, 2011) às imposições do Estado, passaram a usar a fala em alemão de um modo diferente do qual empregavam habitualmente antes da proibição total do ensino em idioma que não o português decretada pela Campanha de Nacionalização no ano de 1942 (BREDEMEIER, 2010).

A continuidade do uso da língua alemã no espaço das escolas da imigração alemã, mesmo que de forma velada, indica um movimento de resistência à condução promovida pelo Estado. Não um rompimento total com o condutor, já que o ensino efetivamente passou a ocorrer apenas no idioma português em tais espaços (BREDEMEIER, 2010), mas uma transgressão sutil que possibilitou aos descendentes de alemães a permanência do uso da língua alemã. Ou seja, a proibição decretada pelo governo de Getúlio Vargas, provocou a criação de um novo modo de condução no contexto dessa forma de vida.

Em sua narrativa, José observou que, após a proibição do uso do alemão na escola, ele e seus colegas continuaram falando em alemão em determinadas situações, mas sempre tendo o 
cuidado para que nenhuma autoridade os ouvisse, pois eles tinham consciência de que aquele ato era cabível de punição. Em suas próprias palavras: "não é que a gente nunca, nunca falava alemão na escola, mas era pouco entende. Como é que a gente nunca ia falar alemão, se a gente sempre falou alemão. Isso também não dá né. Mas era poucas vezes. E só quando não tinha alguma autoridade por perto, pra não nos punir".

O mesmo foi narrado por Helga: "na escola a gente não podia falar alemão, porque era proibido. Mas não era assim que funcionava mesmo. O que acontecia era que quando não tinha ninguém vendo, principalmente nenhum professor, se falava alemão para os outros". No caso de Veni, ela observou que não apenas os alunos continuaram se expressando em alemão quando ninguém poderia puni-los, mas também o professor de sua turma: "quando não tinha ninguém que pudesse ouvir e denunciar, o professor falava em alemão com nós e nós também podia falar'.

Dias (2006) e Paula (2006) observam que durante a Campanha de Nacionalização transcorreram inúmeras denúncias e medidas repressivas a aqueles que não se adaptavam às ações nacionalizadoras, como por exemplo, a insistência do uso da língua alemã como meio de comunicação em espaços públicos. Entre as medidas punitivas mais recorrentes aplicadas nos espaços escolares estão a suspensão e afastamento de professores e diretores, castigos para os alunos "infratores" e comparecimento na escola dos pais de alunos que descumprissem a proibição (DIAS, 2006).

Também há registros e relatos de prisões de professores que teriam sido detidos porque continuaram a falar ou ensinar em língua alemã, ou eram considerados suspeitos de envolvimento com o Partido Nazista (SEYFERTH, 1997). “Estas detenções para 'averiguações' estavam diretamente relacionadas à intensa vigilância da qual a população era alvo e, particularmente, os professores" (LEMOS, 2012, p. 139).

Embora houvesse o perigo de professores e alunos serem acusados de conspiração nazista ao se comunicarem em alemão (WEBER, 2012), os participantes desta pesquisa narraram a ocorrência de uma manutenção do uso da língua alemã no espaço escolar em situações específicas, às quais requeriam dos indivíduos envolvidos certo cuidado para que não fossem ouvidos. Ou seja, esses alunos e os professores passaram a se conduzir de modo alternativo ao que agiam até então. 
Por fim, o último ritual analisado consiste no uso do livro escolar nas escolas da imigração alemã. Pelas narrativas dos participantes, os livros escolares anteriores à Campanha de Nacionalização traziam elementos que se referiam à cultura alemã, mesmo aqueles impressos em português. Esses livros eram considerados, por eles, melhores do que aqueles que passaram a ser utilizados posteriormente, porque estes últimos não traziam referências à cultura alemã, referências que eram valorizadas.

Analisando o conteúdo dos livros escolares utilizados até 1938 nas escolas da imigração alemã, Kreutz (1999) considera que estes tratavam de questões relacionadas ao contexto histórico e geográfico do Brasil, assim como também abordavam os símbolos nacionais brasileiros. Entretanto, eles não tratavam exclusivamente da cultura brasileira. Eram trabalhadas simultaneamente "referências étnico-culturais alemãs, no modo de ser da alma alemã" (KREUTZ, 1999, p. 152). Algo que foi referenciado pelos participantes desta pesquisa e que era tido como algo positivo na avaliação deles, pois remetia à sua descendência.

Renata, por exemplo, observou que os livros escolares utilizados em sua escola antes da Campanha de Nacionalização eram, em sua maioria, escritos em alemão. Segundo ela, " a gente aprendia muitas coisas da vida alemã nesses livros e eu gostava porque nasci lá né e fazia parte das minhas raízes. Mas não é que tinha coisas só da Alemanha não, eles falavam do Brasil também, mas eles não eram só das coisas do Brasil como aconteceu mais tarde”. Ela recordou que na sua avaliação e de seus colegas, estes livros eram melhores: "é que eles também achavam os livros que a gente tinha antes melhor, porque fazia a gente aprender coisas da nossa terra natal'.

A mesma avaliação foi realizada por Germano em relação aos livros escolares anteriores às medidas nacionalistas: "porque assim, na escola a gente aprendeu também das coisas de lá, e nesses livros tinha. Eram bons. Mas aí depois esses livros a gente não podia mais usar, aí a gente só aprendia da história do Brasil, do português, dos estudos daqui mesmo. Não tinha mais nada que falava dos alemães".

Helga destacou que as referências da cultura alemã presentes nos livros escolares eram importantes para ela e seus colegas, pois "em algumas coisas eles falavam das coisas que eram da cultura dos alemães, da nossa origem e isso era bom pra poder manter as tradições com nós, até mesmo no colégio". 
JUNGES, Débora de Lima Velho. Preservação do Deutschtum nas escolas da imigração alemã no período da Campanha de Nacionalização.

Tais narrativas reforçam o argumento de que, para os imigrantes alemães e seus descendentes, preservar o Deutschtum era algo significativo em suas vidas e estava relacionado à manutenção de uma nacionalidade alemã, mesmo sendo cidadãos brasileiros. Nesse contexto, as escolas da imigração alemã estabeleciam uma espécie de vínculo entre os alunos descendentes de alemães e a cultura alemã com o uso de livros escolares que traziam referências à esta cultura.

\section{Considerações finais}

A partir da análise realizada com base nos excertos das narrativas apresentadas pelos participantes desta pesquisa, alguns pontos merecem destaque no que tangem à fala em favor da manutenção da Deutschtum entre os imigrantes alemães e seus descendentes. Primeiramente, o uso da língua alemã, os costumes e as tradições de origem germânica foram passadas pelas famílias dos participantes e essas práticas os constituíram como conservadores e defensores da germanidade, levando-os a repassar as práticas aprendidas para seus filhos. Há, nas narrativas apresentadas, um sentimento de orgulho por pertencer a famílias que migraram da Alemanha e por possuírem "sobrenome alemão".

Além disso, percebe-se uma forte identificação dos participantes com o "ser alemão/colono" no que diz respeito a sua nacionalidade e o entendimento de "ser brasileiro" ao se tratar de sua cidadania. Ou seja, os participantes concebiam as noções de nacionalismo e cidadania como dois conceitos distintos, o que se aproxima com o entendimento jurídico alemão. Assim sendo, o Deutschtum operava na vida dos imigrantes alemães e seus descendentes, subjetivando-os de tal modo que eles se percebiam como colonos de descendência alemã e cidadania brasileira.

Como argumentado, o germanismo defendia que, independente do lugar em que imigrantes alemães se estabelecessem, o Deutschtum deveria ser preservado. Desse modo, a transmissão dos valores nacionais alemãs deveriam ser passados para as gerações futuras, como meio de manter os laços nacionalistas com a Alemanha.

Além do que era transmitido e ensinado em relação à cultura germânica no contexto das famílias, também o espaço escolar cumpria esse papel. Isto porque tratavam diretamente de assuntos referentes à cultura alemã, uma parcela dos professores veio da Alemanha para lecionar nas escolas da imigração e, em alguns casos, as escolas eram financiadas com recursos estrangeiros que tinham como pressuposto ideológico a manutenção do Deutschtum. 
Quando se instaurou a Campanha de Nacionalização, com suas diversas medidas que afetaram diretamente as escolas da imigração alemã em relação às condições de permanência de seu funcionamento, “ações advindas dela não agradaram o governo alemão, porque este não entendia como, durante mais de 100 anos, foi permitida a atuação de escolas e igrejas alemãs e agora, de uma hora para outra, tudo estava proibido" (RAHMEIER, 2009, p. 162). Para a embaixada alemã no Brasil e o Partido Nazista, a preocupação com o futuro das escolas da imigração alemã se dava em relação ao papel que elas exerciam em favor da perpetuação de características étnicas.

Todavia, apesar da preocupação política da Alemanha com as medidas impostas sobre as escolas da imigração alemã, as ações não se constituíram como motivo para o desencadeamento de conflitos diplomáticos entre os dois países. Tanto o embaixador alemão quanto o Partido Nazista sugeriram às escolas da imigração alemã que essas se adaptassem às leis brasileiras. Este fato "dificultou em muito o trabalho dos professores vindos da Alemanha e impediu que os órgãos partidários e governamentais alemães gerenciassem as escolas alemãs no Brasil" (RAHMEIER, 2009, p. 136).

Nas escolas, os princípios norteadores do germanismo eram transmitidos a partir de diversos rituais escolares (tais como a prática de entoar o hino, o uso da língua alemã e os conteúdos abordados nos livros didáticos). Como explicitamos por meio das narrativas, estes princípios foram, em alguns casos, preservados e, até mesmo, reforçados no período da Campanha de Nacionalização em forma de rituais escolares "adaptados" às condições impostas pelas medidas de Estado.

\section{Referências}

ARENDT, Isabel Cristina. Representações de germanidade, escola e professor no Allgemeine Lehrerzeitung für Rio Grande do Sul: Jornal Geral para o professor no Rio Grande do Sul. 2005. 292p. Tese (Doutorado em História) - Programa de Pós-Graduação em Educação, Universidade do Vale do Rio dos Sinos, São Leopoldo, 2005.

BUJES, Maria Isabel Edelweiss. A invenção do eu infantil: dispositivos pedagógicos em ação. Revista Brasileira de Educação, Rio de Janeiro, n. 21, p. 17-39, set./dez. 2002.

BREDEMEIER, Maria Luísa Lenhard. O português como segunda língua nas escolas da imigração alemã: um estudo do Jornal da Associação de Professores Teuto-Brasileiros Católicos do Rio Grande do Sul (1900-1939). 2010. 242p. Tese (Doutorado em Educação) - Programa de Pós-Graduação em Educação, Universidade do Vale do Rio dos Sinos, São Leopoldo, 2010. 
JUNGES, Débora de Lima Velho. Preservação do Deutschtum nas escolas da imigração alemã no período da Campanha de Nacionalização.

DIAS, Gustavo Tentoni. Cultura, política e alfabetização no Brasil: a 'Segunda Campanha de Nacionalização’ do ensino (1938-1945). 2006. 219p. Dissertação (Mestrado em Ciências Sociais) Programa de Pós-Graduação em Ciências Sociais, Universidade Federal de São Carlos, São Carlos, 2006.

FONSECA, Maria Angela Peter da. Estratégias para a preservação do germanismo (Deutschtum): gênese e trajetória de um collegio teutobrasileiro urbano em Pelotas (1898-1942). 2007. 158p. Dissertação (Mestrado em Educação) - Universidade Federal de Pelotas, Pelotas, 2007.

FOUCAULT, Michel. A hermenêutica do sujeito: curso no Collège de France (1981-1982). 3. ed. São Paulo: Martins Fontes, 2011a.

FOUCAULT, Michel. Microfísica do poder. 17. ed. Rio de Janeiro: Graal, 2002.

FOUCAULT, Michel. História da sexualidade 2: o uso dos prazeres. 8. ed. Rio de Janeiro: Edições Graal, 1998.

GRÜTZMANN, Imgart. A mágica flor azul: canções, romantismo, nostalgia e continuidade no germanismo. Revista Escritas, Araguaína, v. 1, n.1, p. 1-29, jan. 2008.

HALL, Stuart. A identidade cultural na pós-modernidade. 11. ed. Rio de Janeiro: DP\&A, 2006.

JØRGENSEN, Kenneth Mølbjerg; BOJE, David M. Resituating narrative and story in business ethics. Business Ethics: A European Review, Reino Unido, v. 19, n. 3, p. 253-264, jul. 2010.

JØRGENSEN, Kenneth Mølbjerg; NUNEZ, Heilyn Camacho. Ethics and organizational learning in higher education. In: THE INTERNATIONAL CONFERENCE ON HIGHER EDUCATION PROCEEDING, Heredia, Costa Rica, 2010. v. 1, n. 1, p. 1-13, mar. 2010.

KREUTZ, Lúcio. Escolas étnicas no Brasil e a formação do Estado Nacional: a nacionalização compulsória das escolas dos imigrantes (1937-1945). Poiésis, Tubarão, v. 3, n. 5, p. 71-84, jan./jun. 2010.

KREUTZ, Lúcio. Periódicos na literatura educacional dos imigrantes alemães no RS (1900-1939). REUNIÃO ANUAL DA ANPED, 30., Caxambu, Caxambu, MG. Anais [...]. Caxambu, MG: ANPED, 2007. p. 1-13.

KREUTZ, Lúcio. A representação de identidade nacional em escolas da imigração alemã no Rio Grande do Sul. História da Educação (UFPel), Pelotas, v. 3, n. 5, p. 141-165, 1999.

KREUTZ, Lúcio. Material didático e currículo na escola teuto-brasileira do Rio Grande do Sul. São Leopoldo: UNISINOS, 1994.

LEMOS, Vanessa dos Santos. Propaganda e coerção na política educacional do Estado Novo (19371945). 2012. 182p. Dissertação (Mestrado em História) - Programa de Pós-Graduação em História, Universidade Federal de Pelotas, Pelotas, 2012.

MARÍN-DÍAZ, Dora Lilia. Autoajuda e educação: uma genealogia das antropotécnicas contemporâneas. 2012. 310p. Tese (Doutorado em Educação) - Faculdade de Educação, Universidade Federal do Rio Grande do Sul, Porto Alegre, 2012.

NEUMANN, Rosane Marcia. Uma Alemanha em miniatura: o projeto de imigração e colonização étnico particular da Colonizadora Meyer no noroeste do Rio Grande do Sul (1897-1932). 2009. 632p. Tese (Doutorado em História) - Faculdade de Filosofia e Ciências Humanas, PUCRS, Porto Alegre, 2009.

PAULA, José Fabiano de. "O que a escola começa, o exército continua": a campanha de nacionalização durante o Estado Novo nos núcleos coloniais teuto-brasileiros do Rio grande do Sul. 2006. 221p. Dissertação (Mestrado em Educação nas Ciências) - Programa de Pós-Graduação em Educação nas Ciências, UNIJUÍ, Ijuí, 2006. 
JUNGES, Débora de Lima Velho. Preservação do Deutschtum nas escolas da imigração alemã no período da Campanha de Nacionalização.

RAHMEIER, Andrea Helena Petry. Relações diplomáticas e militares entre a Alemanha e o Brasil: da proximidade ao rompimento (1937-1942). 2009. 390p. Tese (Doutorado em História) - Faculdade de Filosofia e Ciências Humanas, PUCRS, Porto Alegre, 2009.

RAMBO, Arthur Blásio. A escola comunitária teuto-brasileira católica. São Leopoldo: UNISINOS, 1994.

ROSE, Nikolas. Como se deve fazer a história do eu? Educação e Realidade, Porto Alegre, v. 26, n. 1, p. 33-57, jan. 2001.

SEYFERTH, Giralda. Imigrantes, estrangeiros: a trajetória de uma categoria incomoda no campo político. In: REUNIÃO BRASILEIRA DE ANTROPOLOGIA, 26., 2008. Porto Seguro, Porto Seguro, BA. Anais [...]. Porto Seguro, BA: ABA, 2008. p. 1-20.

SEYFERTH, Giralda. Colonização, imigração e a questão racial no Brasil. Revista USP, São Paulo, n. 53, p. 117-149, mar./maio 2002.

SEYFERTH, Giralda. A assimilação dos imigrantes como questão nacional. Mana, Rio de Janeiro, v. 3, n. 1, p. 95-131, abr. 1997.

SEYFERTH, Giralda. Identidade étnica, assimilação e cidadania: a imigração alemã e o estado brasileiro.

Revista Brasileira de Ciências Sociais, São Paulo, v. 9, n. 26, p. 103-122, out. 1994.

SEYFERTH, Giralda. Nacionalismo e identidade étnica: ideologia germanista e o grupo étnico teutobrasileiro numa comunidade do Vale do Itajaí. Florianópolis: FCC, 1982.

VEIGA-NETO, Alfredo; LOPES, Maura Corcini. Inclusão como dominação do outro pelo mesmo. In: COLÓQUIO INTERNACIONAL MICHEL FOUCAULT. 7., 2011, São Paulo, São Paulo, SP. Anais [...]. São Paulo, SP: PUC-SP, 2011. p. 1-12.

WANDERER, Fernanda. Educação matemática, jogos de linguagem e regulação. São Paulo: Livraria da Física, 2014.

WEBER, Paula Cristina. Representações da integração cultural das comunidades de origem alemã no Rio Grande do Sul do estado novo: um estudo das obras Um rio imita o reno e Longe do reno. 2012. 140p. Dissertação (Mestrado em Letras, Cultura e Regionalidade) - Programa de Pós-Graduação em Letras, Cultura e Regionalidade, Universidade de Caxias do Sul, Caxias do Sul, 2012.

WITT, Marcos Antônio. Em busca de um lugar ao sol: anseios políticos no contexto da imigração e da colonização alemã (Rio Grande do Sul - século XIX). 2008. 428p. Tese (Doutorado em História) -

Faculdade de Filosofia e Ciências Humanas, Pontifícia Universidade Católica do Rio Grande do Sul, Porto Alegre, 2008. 